\title{
Analysis on Preferential Tax Policies of Agricultural Enterprises
}

\author{
Li Chan
}

(College of Modern Economics \& Management JUFE, Nanchang, 330013)

\author{
Keywords: Agricultural enterprises; Taxes; Preferential policies
}

\begin{abstract}
In recent years, the state has taken many measures to support the development of agriculture, such as taking preferential policies to agriculture-related enterprises to promote the adjustment of product structure and expansion of agricultural enterprises, and the development of large-scale production and industrialization of agricultural enterprises so as to promote the efficient development of agriculture. Although there are some problems in the implementation of the various preferential income tax policies in the agricultural tax incentives, the preferential tax policies still have the benefit of expanding the scope of preferential taxation and increasing the preferential tax rate in the agricultural activities of enterprises.
\end{abstract}

\section{Introduction}

Agriculture is weak, and agricultural development can not be separated from the guidance and support of relevant policies. Agricultural industrialization is conducive to overcoming the predicament of low agricultural production efficiency, and making agricultural production scale and industrialization. It is an agricultural development approach advocated and supported by national policies. Agricultural industrialization enterprises play a leading role in the process of agricultural industrialization and play a guiding role. The country once put forward the slogan that "supporting agricultural industrialization enterprises is to support agricultural industrialization", which shows that agricultural industrialization enterprises are important in the layout of agricultural industrialization. status. In order to better develop agricultural leading enterprises, China has formulated many preferential policies for agricultural enterprises, and agricultural enterprises should cherish these policies and make better use of these favorable policies. Improve the company's core competitiveness and enhance the company's operating standards. The rationalization of taxation is related to whether the level of corporate tax burden is scientific and reasonable. It is very important for the agricultural company to correctly interpret the national tax law and rationally arrange the tax burden of the enterprise. A slight oversight in the work may bring passiveness and lossto the taxation work of the enterprise and the benefits are affected. Prior scientific and rational taxation is particularly important, and it is a problem that agricultural enterprises must face.

\section{Agricultural Preferential Policies}

\section{Tax Benefits}

(1) The sale of agricultural products to farmers' professional cooperatives is regarded as the sale of self-produced agricultural products by agricultural producers and exempted from value-added tax;

(2) For tax-free agricultural products purchased by general taxpayers from farmers' professional cooperatives, the deductible VAT input tax amount can be calculated based on the deduction rate of $13 \%$;

(3) VAT is waived for agricultural film, seeds, seedlings, fertilizers, pesticides and agricultural machinery sold by farmers' professional cooperatives to members of the society.

\section{Subsidy Policy}

Encourage new cooperatives such as farmers' cooperatives to obtain funds through loans, financing guarantees, etc., to develop high-standard farmland, and to develop modern agriculture with advanced production technology, moderate operating scale, strong market competitiveness, and sustainable ecological environment. For the loans used for the construction of high-standard 
farmland, the central government will discount interest. Broaden the financing channels, in addition to policy banks, commercial banks, rural credit cooperatives and other financial institutions loans are also included in the scope of interest subsidies. It is allowed to adopt bank loans, financial subsidies, self-financing "three-in-one" and loan-combination methods to attract financial capital to invest in high-standard farmland construction and further accelerate the progress of construction.

\section{Support Policies for Agriculture-Related Projects}

In terms of special support categories, the state also supports farmers' professional cooperatives. The State Agricultural Development Office stipulates in the "Opinions on Launching a New Type of Agricultural Management Body to Apply for Pilot Projects for Comprehensive Development of High-standard Farmland for Agricultural Comprehensive Development", and actively supports the new-type agricultural management entities in applying for the implementation of high-standard farmland construction projects. The project implementation area for individual projects is, in principle, not less than 500 acres in the plain areas of the farmer cooperatives and not less than 300 acres in the hills and mountains. For the comprehensive agricultural land development and management project, the financial subsidies for land per mu shall not exceed 1,500 yuan per mu.

The seven ministries and commissions of the Ministry of Agriculture decided to include farmers' professional cooperatives in the scope of application for agriculture-related projects that are suitable for farmers' professional cooperatives. The supporting funds for agriculture-related project support policies are large and have a relatively small coverage. They need to be filed after the notice of the project. There are many agricultural projects in China for special support. For example, the comprehensive agricultural development loan interest subsidy project requires that the single loan is not Less than 1 million, not more than 60 million. Comprehensive agricultural development and industrialization management projects and land management projects support 800-1.6 million funds. Large-scale farming and breeding farms, centralized gas supply and other biogas projects, supporting funds of 200,000-800,000. The "basket" product production support project supports about one million yuan. Comprehensive agricultural development and industrialization management projects, financial subsidy projects, and leading enterprises drive industrial development and pilot projects for "one county and one special" industry development, supporting 100 million to 3 million of the fund's leading enterprises and 5 to 1.5 million cooperatives.

\section{Agricultural Product Circulation Policy}

Encourage and guide cooperatives to achieve the convergence of production (supply) with various market players such as large supermarket chains, university canteens, and agricultural production companies.

\section{Talent Support Policy}

From the implementation of the modern agricultural talent support program, 1,500 cooperative leaders are trained each year. Government continues to include talent training for farmers' professional cooperatives into the "Sunshine Project", and focus on training leaders of cooperatives, financial personnel, and counselors of grass-roots cooperatives. College students' village officials are encouraged to participate in and organize cooperatives.

\section{Taxation}

Taxation refers to the realization of all the preferential policies provided by the tax law, through the series of activities such as management and investment, within the scope permitted by laws and regulations, in order to maximize the value of the company or maximize the rights of investors. It is a type of financial activity that the tax plan is optimized.

(1) Taxation planning of the entire process of establishment and restructuring

Agricultural enterprises include agricultural production enterprises mainly engaged in agriculture, forestry, animal husbandry, and fishery planting and breeding. The preferential tax policies enjoyed by various types of enterprises are different. They are related to the scale and business projects of enterprises and enterprises engaged in the wholesale of agricultural products enjoy Value-added tax, business tax, income tax deduction and exemption of urban land use tax and real estate tax for agricultural products wholesale land. 
(2) Planning of business accounting process

Agricultural enterprises are engaged in many business projects. Some projects have preferential tax policies, some do not have preferential tax policies, and those that have not been separately accounted for may not enjoy preferential tax policies; they must be rigorously categorized in accounting to separately account for tax exempt items and taxable items. Income, costs, and expenses are maximally enjoyed in accordance with applicable tax incentives. In the premise of not affecting the quality of financial accounting information, tax accounting direction should be focused as far as possible to avoid losing tax incentives due to non-compliance of tax accounting matters.

(3) Planning of tax filing

The state has given preferential tax policies to agricultural enterprises, so that enterprises can not really experience such preferential policies. Only after enterprises fulfill relevant obligations can they really enjoy policy preferences; the general tax incentives are managed in advance for filing and afterwards. Two kinds of relevant information are submitted, and the specific division is determined by the tax authorities; China's promulgated so many preferential tax policies, as long as it is not clearly approved, must be implemented for record management.

\section{Measures and Impacts of Agricultural Taxation}

Among various economic stimulus policies, fiscal and taxation policies are the most important and effective means. In recent years, the Chinese government has attached great importance to the structural adjustment and accelerated development of the agro-processing industry, taking it as an important part of promoting agricultural and rural economic development and strategic adjustment of the national economic structure for a long period to come, and has issued some fiscal and taxation tilt policies.

Using the methods of normative analysis, empirical analysis, comparative analysis and other methods, taking the "Agricultural Processing Industry Finance and Taxation Policy Study" as the theme, based on the basic fiscal and taxation theory, the development process of China's agricultural product processing finance and taxation policy and the new problems it faces are summed up. Countries such as the European Union, Japan, and South Korea have developed fiscal and taxation policies for agricultural products processing industry, combined with the status quo and existing problems of fiscal and taxation policies for agricultural products processing industry in China, and put forward policy adjustments and improvements that the Chinese government should take in the development of agricultural products processing industry.

First, giving priority to the development of leading industry theory, unbalanced growth theory, development pole theory, and supply-side taxation thoughts provide a theoretical basis for the rapid development of fiscal and taxation support for the agricultural product processing industry; the status of China's agricultural product processing industry in the national economy and foreign advanced The gap between countries makes fiscal and taxation policy support more urgent and necessary.

Second, the effect of fiscal and taxation policy support has already begun. In the face of the problems existing in the agricultural product processing industry, it is necessary for China to adjust and improve both financial and tax support measures, support methods, and support.

Third, China's current fiscal policy can be divided into four aspects: fiscal investment policy, financial subsidy policy, policy-based credit, and preferential taxation policy.

A sound financial and taxation policy support system has enabled the rapid development of the national agricultural product processing industry.

\section{Conclusion}

In short, to better develop agricultural leading enterprises, China has formulated many preferential policies for agricultural enterprises, and agricultural enterprises should cherish these policies and make better use of these favorable policies. Enhance the company's core competitiveness and enhance the company's operating standards. Properly carrying out taxation is related to whether the 
level of corporate tax burden is scientific and reasonable. It is very important as an agricultural company to correctly interpret the national tax law and rationalize the tax burden of the enterprise. A slight oversight in the work may bring passiveness and loss to the taxation work of the enterprise and the benefits are affected. Prior scientific and rational taxation is particularly important, and it is a problem that agricultural enterprises must face.

\section{Acknowledgement}

Fund project: Jiangxi provincial university humanities and social sciences research project(No.GL17109)

\section{References}

[1]Huo Y, Wen X M, University S. Management strategy of Xinjiang agricultural listed companies and reasonable tax countermeasures[J]. Arid Land Geography, 2015.

[2]Liu Z D. Effect of Governmental Subsidies and Preferential Tax Policies on the Operating Performance of Listed Agricultural Companies from the West[J]. Journal of Xian University of Finance \& Economics, 2011.

[3]Lan X Y. Thinking of the Preferential Tax Policies for School-enterprise Cooperation of Vocational Education in China[J]. Vocational \& Technical Education, 2013.

[4]Faychuk O. Modern Trends In Preferential Bank Crediting Development Of Agricultural Enterprises Of Kyiv Region[J]. Ukrainian Journal Ekonomist, 2013:18-21.

[5]Schroeder K G, Meyers W H, Schmitz A, et al. Policy issues and prospects for Ukraine's grain exports.[J]. 2013.

[6]Zhang Y, Wang Z. Trend Analysis of High-Tech Enterprises' Application of Preferential Tax Policies in Shanghai[J]. Forum on Science \& Technology in China, 2015.

[7]Liu D. Improving the Tax Policies Benefiting Farmers[J]. Business Economy, 2013.

[8]Nepochatenko O, Leleka V. Problems of Preferential Regime of Agricultural Business Direct Taxation in Ukraine[J]. Accounting \& Finance, 2015, 59(1):667-674.

[9]Li B. A Study on Agricultural Tax Policies in Developed Countries and Its References for China[J]. International Taxation in China, 2010.

[10]Yang H. Study on the Adjustment of Economic Structure and the Structural Tax Reduction Policy[J]. China Business \& Market, 2013.

[11]Fan H X. International Experience and Optimizing design Study on the Real Estate Tax Preferential Policy[J]. Journal of Inner Mongolia University, 2012.

[12]Ming-Qiang X U, Jiang Y M. On Urgent Change of the Idea of Large-Scale Arable Land Transferring to Enterprise[J]. Journal of Jiangxi University of Finance \& Economics, 2015. 